\title{
Alterations in Some Haematological Parameters of The African Snakehead: Parachanna africans Exposed to Cadmium
}

\author{
Ovie KORI-SIAKPERE*, Urowoli IKOMI*
}

Delta State University, Department of Animal and Environmental Biology, Abraka, Nigeria; oviekori@yahoo.com ( ${ }^{*}$ corresponding author)

\begin{abstract}
The haematological alterations produced on exposure of the African snakehead, Parachanna africans to the sublethal concentration $(0.0,0.1,1.0$ and $10.0 \mathrm{mg} / \mathrm{L})$ of cadmium $\left(\mathrm{Cd}^{2+}\right)$ for 21 days have been studied. Red blood cell (RBC) count, haemoglobin $(\mathrm{Hb})$ concentration, haematocrit $(\mathrm{Hct})$, the mean corpuscular haemoglobin $(\mathrm{MCH})$ and the mean corpuscular volume (MCV) levels were decreased with an increase in exposure concentration, but the level of the mean corpuscular haemoglobin concentration (MCHC) was increased. These alterations could be attributed to haemolysis and impairment of haemoglobin synthesis, resulting in a hypochromic microcytic anaemia, induced by exposure to cadmium. Cadmium exposure also caused significant decreases in white blood cell (WBC) count. The primary consequence of the observed changes in total and differential leucocyte counts in stressed fish was attributed to suppression of the immune system and increased susceptibility to disease. Plasma glucose and total plasma protein concentrations were significantly decreased; showing that cadmium affects the fish energy metabolism. The present study thus confirmed that haematological parameters are very sensitive indicators of fish organism response to chemicals in this case cadmium.
\end{abstract}

Keywords: cadmium, glucose, haematological parameters, Parachanna africans, protein, sublethal effect

\section{Introduction}

Heavy metals are inorganic elements essential for growth in trace or very minute quantities, toxic and poisonous in relatively higher concentrations; biologically undegradable but easily assimilated and bioaccumulated in the protoplasm of aquatic organisms (Egborge, 1994). They are introduced into the aquatic environments by industrial, domestic and mining activities (Pourang, 1996). Heavy metals are attributed to adverse effects on the health of biota and indigenous populations due to their toxicity and bioaccumulative tendencies within the environment (Vare et al., 2006). Cadmium is one of the listed extremely hazardous substances. It belongs to the group IIb in the periodic table, occurring as a soft bluish white metal, solid in its standard state. It enters surface water with the discharge of industrial wastes or by leaching of soil to which sewage sludge is deposited. It accumulates in the tissues of mammals and aquatic organism causing acute haemolytic crisis resulting in severe anaemia, hyperglycaemia among other effects in mammals (Freiberg et al., 1974). The toxicity and toxic effects of cadmium generally result from the binding of the metal with reactive and/or complexity group leading to inhibition of enzymatic process, possibly disturbing general growth, development and reproduction (WHO, 1992). It is biologically very reactive and therefore gives rise to both acute and chronic poisoning. Nariagu and Sprague (1987) emphasized elaborately on effects of cadmium on aquatic organisms. Many reports are available on the effect of $\mathrm{Cd}$ on fish blood. Blood is a good bio indi- cator or a diagnostic tool to study the problem in organ function. The measurement of haematological changes of fish under exposure to any toxicant may be used to predict effects upon chronic exposure. The objective of present work was to determine the effects of sublethal concentrations of cadmium to haematological parameters in the African snakehead, Parachanna africans.

\section{Materials and methods}

Healthy live specimens of Parachanna africans were obtained were obtained from local fish market at Ughelli, Delta State, Nigeria; transported to the laboratory and kept in glass aquaria supplied with clean water. The fish were checked for injury and disease, and then washed in $0.1 \%$ potassium permanganate $\left(\mathrm{KMnO}_{4}\right)$ solution for 5 minutes. All fish were maintained in the laboratory for a minimum period of two weeks during which they were fed with commercial fish food.

Stock solution of cadmium was prepared from $2.37 \mathrm{~g}$ of cadmium acetate $(\mathrm{CH} 3 \mathrm{COO})_{2} \cdot \mathrm{Cd}_{2} 2 \mathrm{H}_{2} \mathrm{O}$ equivalent to $1 \mathrm{~g}$ cadmium metal was dissolved in 1 litre of distilled water to form the stock solution. From this stock solution, various concentrations used in the investigations were prepared.

The containers used, consisted of large plastic containers of 150 litres capacity. The upper part of each containers were covered with a lid made of fine polyethylene gauze screen of $1 \mathrm{~mm}$ mesh size. Each experimental set up and 
30

control (each aquarium) were stocked with 10 fish specimen in each of the concentrations tested.

After acclimatization, the experimental fish were divided into four (4) groups to assess the sublethal effect of cadmium on haematological parameters. The first group was kept in fresh untreated water and used as control while the other three groups were exposed to the sublethal concentrations $(0.1,1.0$ and $10.0 \mathrm{mg} / \mathrm{L})$ of cadmium in the water. Fish specimens were starved for 24 hours, weighed and then introduced into the test solution/water (10 specimens in each aquarium).

Water quality parameters were determined at three days interval using standard laboratory methods as described by APHA (1998) and the exposure media replaced. The parameters measured were temperature, $\mathrm{pH}$, dissolved oxygen, free carbon dioxide and total alkalinity.

At the end of the exposure period of twenty-one (21) days the fish were taken from the control and test tanks, sacrificed and subjected to the analysis described below.

Five fish were caught individually in a small hand net from the containers. After the preliminary investigation of the length and weight, the fish were then placed belly upwards and blood samples obtained from the caudal circulation with the aid of a heparinised $2 \mathrm{~cm}^{3}$ disposable plastic syringe and a 21 gauge disposable hypodermic needle. The use of plastic syringe is a necessary precaution with fish blood because contact with glass results in decreased coagulation time (Smith et al., 1952). The site chosen for puncture (about $3-4 \mathrm{~cm}$ from the genital opening) was wiped dry with tissue paper to avoid contamination with mucus. The needle was inserted at right angle to the vertebral column of the fish and gently aspirated during penetration. It was then pushed gently down until blood started to enter as the needle punctured a caudal blood vessel. Blood was taken under gentle aspiration until about $1 \mathrm{~cm}^{3}$ has been obtained; then the needle was withdrawn and the blood gently transferred into heparinized plastic containers. The samples were then mixed gently but thoroughly. Some blood samples were used for the measurement of haematocrit, haemoglobin concentration, red blood cell count and total white blood cell count. Plasma was obtained from blood samples by centrifugation and then drawn into a $1 \mathrm{~cm}^{3}$ plastic syringe transferred into a universal bottle and stored in a refrigerator and later used for the determination of plasma glucose and total plasma protein. All determinations were carried out in duplicates for each sample.

The haemoglobin concentration of the blood samples was determined in duplicate by the cyanmethaemoglobin method (Larsen and Snieszko, 1961). The haematocrit was determined by the microhaematocrit method of Snieszko (1960). The red blood cells were enumerated in an improved Neubaeur haemocytometer, using Hendricks diluting fluid. The total white blood cell counts were similarly enumerated in an improved Neubaeur haemocytometer using Shaw's diluting fluid. The haematological indices: mean corpuscular haemoglobin concentration $(\mathrm{MCHC})$, mean corpuscular haemoglobin $(\mathrm{MCH})$ and mean corpuscular volume (MCV) were calculated from the equations given by Anderson and Klontz (1965).

$$
\begin{aligned}
\operatorname{MCHC}(\%) & =\frac{\text { Haemoglobin }(\mathrm{g} \%)}{\text { Haematocrit }(\%)} \times 100 \\
\operatorname{MCH}(\rho \mathrm{g}) & =\frac{\text { Haemoglobin }(\mathrm{g} \%)}{\text { Erythrocyte count }(\text { per } / \mathrm{L})} \times 10 \\
\operatorname{MCH}\left(\mu^{3}\right) & =\frac{\text { Haematocrit }(\%)}{\text { Erythrocyte count }(\text { per } / \mathrm{L})} \times 10
\end{aligned}
$$

The plasma glucose and total plasma protein were determined with aid of Randox commercial diagnostic kits.

All results obtained from the sublethal tests were subjected to statistical analysis using one-way analysis of variance (ANOVA) to test differences between the various levels of sublethal concentrations of cadmium. Multiple comparisons of the means were analyzed by the Duncan tests. All analyses were performed using the software programme (GraphPads Prism Software version 5.0, San Diego, CA). Results were considered significant at the $95 \%$ confidence level $(\mathrm{P}<0.05)$.

\section{Results}

The water quality parameters of the diluting water used in the tests and determined by standard methods are presented in Tab. 1.

Haematological alterations resulting from the exposure of Parachanna africans to the various sublethal concentrations of cadmium in the water are presented in Fig. 1. Red blood cell count (RBCC), haemoglobin $(\mathrm{Hb})$ concentration, haematocrit (Hct) and white blood cell count (WBCC) were decreased with an increase in exposure concentration; being statistically significant $(\mathrm{P}<0.05)$ at the higher concentrations of 1.0 and $10 \mathrm{mg} / \mathrm{L}$ cadmium.

Alteration in the haematological indices of $\mathrm{MCHC}$, $\mathrm{MCH}$ and $\mathrm{MCV}$; and plasma glucose and total plasma protein in Parachanna africans following exposure to the various concentrations of cadmium in the water are presented in Fig. 2. The mean corpuscular haemoglobin $(\mathrm{MCH})$ and the mean corpuscular volume (MCV) mean levels were decreased with an increase in exposure concentration, but the level of the mean corpuscular haemoglobin concentration (MCHC) was increased. Plasma glucose and total plasma protein concentrations were also significantly $(\mathrm{P}<0.05)$ decreased.

Tab. 1. Water quality parameters of dilution water used in the sublethal tests

\begin{tabular}{lc}
\hline \multicolumn{1}{c}{ Parameter } & Values \\
\hline $\mathrm{pH}$ & $6.56 \pm 0.52$ \\
Temperature & $28.8 \pm 1.2^{\circ} \mathrm{C}$ \\
Dissolved oxygen & $6.96 \pm 0.72 \mathrm{mg} / \mathrm{L}$ \\
Free carbon dioxide & $5.45 \pm 0.09 \mathrm{mg} / \mathrm{L}$ \\
Alkalinity & $34.6 \pm 1.34 \mathrm{mg} / \mathrm{L}$ \\
Hardness & $126.84 \pm 9.08 \mathrm{mg} / \mathrm{L}$ \\
Turbidity & $0.34 \pm 0.07 \mathrm{mg} / \mathrm{L}$ \\
\hline
\end{tabular}



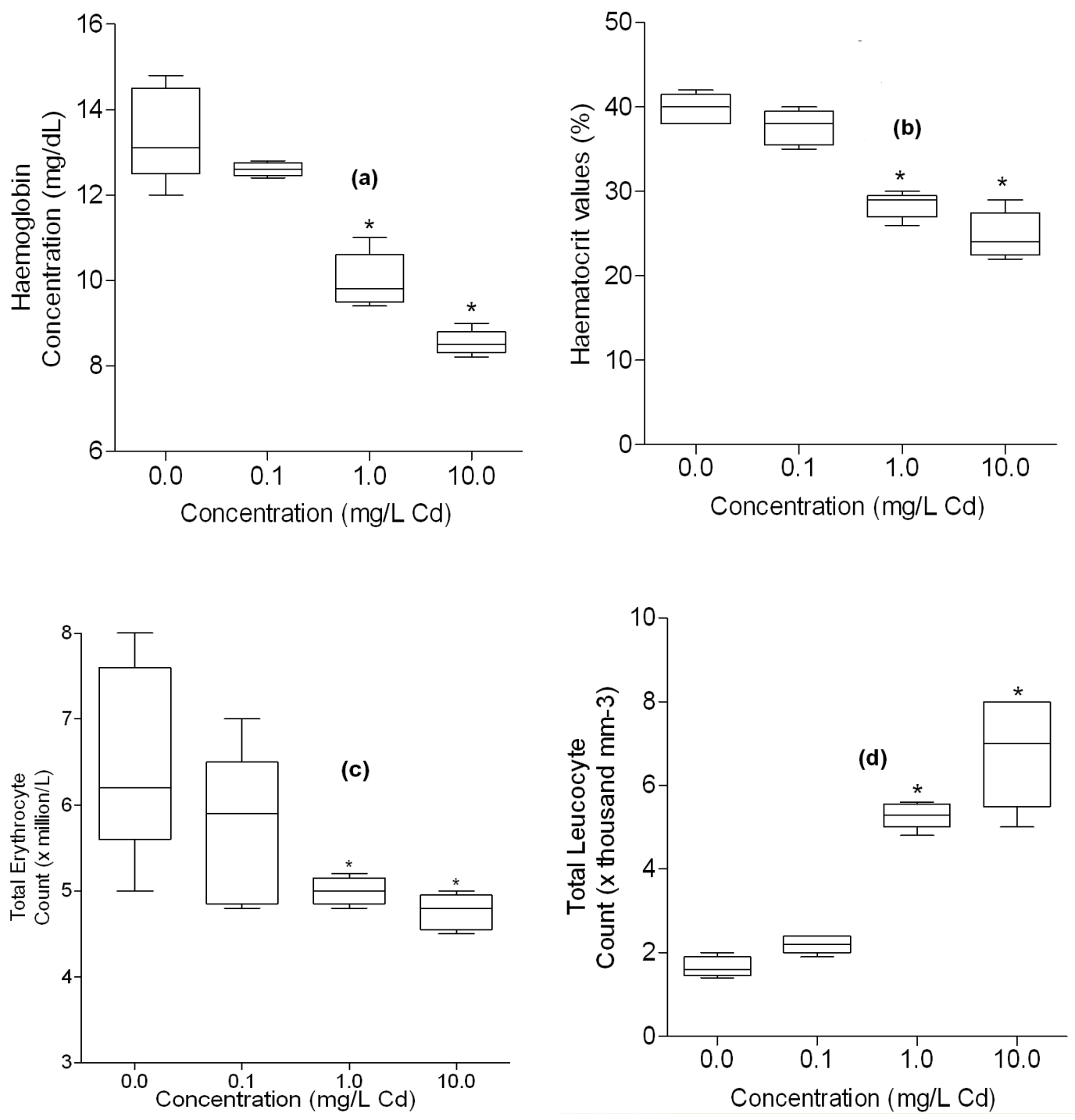

Fig. 1. Alteration in haemoglobin (a), haematocrit (b), total erythrocyte count (c) and total leucocyte count (d) in Parachanna africans following 21 days exposure to the various concentrations of cadmium in the water. Each column represents the mean value and vertical bars indicate the standard error of the mean. Asterisks represent statistical significance at 0.05 level

\section{Discussion}

The results obtained in the present study revealed a significant response in the haematological variables in the cadmium $\left(\mathrm{Cd}^{2+}\right)$ exposed fish both in respect to concentration and exposure time. The statistically significant $(\mathrm{P}<0.05)$ decrease in many values of the haematological parameters studied is not uncommon in fish exposed to sublethal concentrations of toxicants and therapeutic agents. Similar reduction in haematological indices has been reported by Musa and Omoregie (1999) following exposure of C. gariepinus to sublethal concentrations of the therapeutant: malachite green. Omoregie et al. (1994) also made similar observations when Oreochromis niloticus was exposed to sublethal concentrations of formalin. The general reduction of the blood parameters is an indication of anaemia caused by exposure of Parachanna africans to cadmium in this study.
The decreases in haemoglobin concentration signifies that the fish's ability to provide sufficient oxygen to the tissues is restricted considerably and will result in decrease of physical activity (Nussey et al., 1995a; Wepener et al., 1992). The significant decrease in the haemoglobin concentrations may also be due to either an increase in the rate at which the haemoglobin is destroyed or to a decrease in the rate of haemoglobin synthesis (Reddy and Bashanihideen, 1989). Buckley et al. (1976) reported that prolonged reduction in haemoglobin content is deleterious to oxygen transport and any blood dyscrasia and degeneration of the erythrocytes could be ascribed as pathological conditions in fishes exposed to toxicants.

Significant decreases in the haematocrit values recorded after exposure to cadmium are indicative of anaemia and haemodilution possibly due to gill damage or/and impaired osmoregulation (Larsson et al., 1985). 

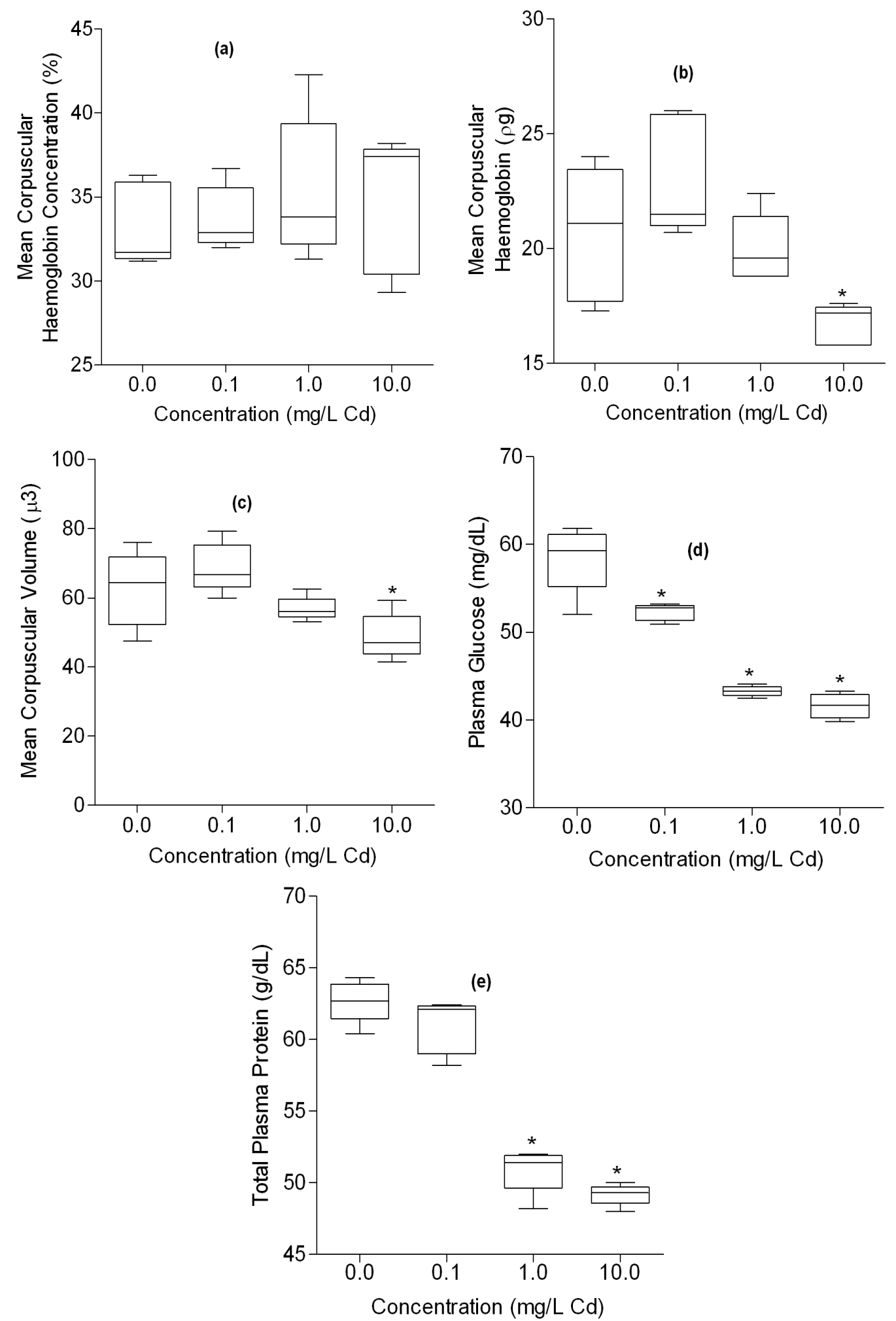

Fig. 2. Alteration in MCHC (a), MCH (b), MCV (c) plasma glucose (d) and total plasma protein (e) in Parachanna africans following 21 days exposure to the various concentrations of cadmium in the water. Each column represents the mean value and vertical bars indicate the standard error of the mean. Asterisks represent statistical significance at 0.05 level

Changes in erythrocyte counts have been reported by Wedemeyer and Yasutake (1977) and Clarke et al. (1979) to be strong indicators of stress due to presence of toxicants or pollutants in the aquatic environment. Reduction in erythrocytes reported in the present study indicated that the experimental fish, became anaemic, which Wedemeyer et al. (1984) attributed to haemodilution resulting from impaired osmoregulation across the gill epithelium. 
Similar reductions in erythrocytes in Nile tilapia exposed to Gammalin 20 and Actellic 25EC have been reported by Omoregie et al. (1990). The reduction in the total erythrocyte count could also be attributed to the destruction of the erythrocytes, thereby limiting their synthesis. Similar trends in erythrocytes in fishes exposed to various toxicants have also been observed by other workers (Koyama and Ozaki, 1984; McLeay, 1973; Smit et al., 1979; Srivastava and Narain, 1985).

Leucocytosis, an increase in the total leucocyte count observed in the present study has been attributed to several factors like increase in thrombocytes, lymphocytes or squeezing of WBCs in peripheral blood (Agrawal and Srivastava, 1980). Increase in the total leucocyte counts could be due to stimulated lymphopoiesis and/or enhanced release of lymphocytes from lymphomyeloid tissues. Such lymphocyte response might be due to the presence of toxic substances or may be associated with the pollutant induced damage. The leucocytosis reported in Oreochromis mossambicus after exposure to copper (Nussey et al., 1995a, b) and found in Prochilodus scrofa (Mazon et al., 2002) may be attributed to increased leucocyte mobilization to protect the body against infections in cadmium-damage tissue. Thus, the primary consequence of the observed changes in leucocyte count in stressed fish is suppression of the immune system and increased susceptibility to disease (Wedemeyer and Wood, 1974).

The calculated haematological indices, MCHC, $\mathrm{MCH}$, and MCV have a particular importance in the diagnosis of anaemia in most animals (Jackson, 2007). The perturbations in these haematological indices (increase $\mathrm{MCV}$, decrease of $\mathrm{MCH}$ and $\mathrm{MCHC}$ ) in the present study may be attributed to a defence against the toxic effect of cadmium through the stimulation of erythropioesis or may be related to the decrease in RBCs, $\mathrm{Hb}$ and $\mathrm{Hct}$ due to exaggerated disturbances that occurred in both metabolic and haemopoietic activities of fish exposed to sublethal concentrations of pollutants (Mousa, 1999). The decrease in MCH and MCV coupled with low haemoglobin content indicates that the red blood cells have shrunk, either due to hypoxia or microcytic anaemia; microcytosis been due to the decrease in the haematocrit values, indicative of a hypochromic microcytic anaemia (Shakoori et al., 1991). In contrast to the present findings, increases in $\mathrm{Hb}$ and $\mathrm{MCH}$ values have reported in Tilapia mossambica exposed to cadmium chloride (Aziz et al., 1993), Ctenopharyhgodon idella exposed to sublethal doses of mercuric chloride (Shakoori et al., 1991) and Oncorbynchus mykiss exposed to cyperthrin (Atamanalp et al., 2002). The MCHC is a good indicator of red blood cell swelling (Wepener et al., 1992). The significant decreases in the MCHC values in the exposed fish are thus probably an indication of swelling of the red blood cells and/or a decrease in haemoglobin synthesis.

\section{Conclusions}

Haematological parameters related to oxygen transport (RBCC, Hct and $\mathrm{Hb}$ ), defense mechanisms (WBCC) and the calculated indices showed overall differences between control and experimental groups. Therefore, haematological parameters are involved in the response of the African snakehead to cadmium under the experimental conditions. The present study thus confirmed that haematological parameters are very sensitive indicators of fish organism response to chemicals in this case cadmium.

\section{References}

Agrawal SJ, Srivastava AK (1980). Effect of endosulfan on certain aspects of haematology of the fish, Channa punctatus. Toxicology 17:97-102.

Anderson D, Klontz GW (1965). Basic haematology for the fish culturist. Ann NW Fish Culturist Conf 16:38-41.

APHA (1998). Standard methods for examination of water and Waste water. $20^{\text {th }}$ Ed. American Public Health Association, Washington D.C. 1076 p.

Atamanalp M, Yank T, Halilolu I, Aras MS (2002). Alterations in the haematological parameters of rainbow trout (Oncorhynchus mykiss) exposed to cypermethrin. Isr J Aquacult-Bamidgeh 54:99-103.

Aziz F, Amin M, Shakoori AR (1993). Toxic effects of cadmium chloride on the haematology of fish, Tilapia mossambica. Proc Pak Cong Zoology 13:141-154.

Buckley JA, Whitmore CM, Matsuda RI (1976). Changes in blood chemistry and blood cell morphology in coho salmon, Oncorhynchus kisutch following exposure to sublethal levels of total residual chlorine in a municipal wastewater. J Fisheries Res Board 33:776-782.

Clarke S, Whitemoere JR, Mcmanou R (1979). Considerations of the blood parameters of largemouth, Micropterus salmoides. J Fish Biol 4:147-158.

Egborge ABM (1994). Water pollution in Nigeria: biodiversity and chemistry of Warri River. Ben-Miller Books Nigeria Ltd. 27-59 p.

Freiberg LT, Piscator M, Nordberg G, Kellstrom T (1974). Cadmium in the environment. $2^{\text {nd }} \mathrm{Ed}$. Chemical Rubber Co Press Inc Florida $248 \mathrm{p}$.

Jackson ML (2007). Veterinary clinical pathology: an introduction; Wiley Interscience Publication, $363 \mathrm{p}$.

Koyama J, Ozaki H (1984). Haematological changes in fish exposed to low concentrations of cadmium in the water. Bull Jap Soc Fish Sci 50:199-203.

Larsen HN, Snieszko SF (1961). Comparison of various methods of determination of haemoglobin in trout blood. The Progres Fish-Culturist 23:8-17.

Larsson A, Haux C, Sjobeck M (1985). Fish physiology and 
34 metal pollution. Results and experiences from laboratory and field studies. Ecotoxicol Environ Safety 9:250-281.

Mazon AF, Monteiro EAS, Pinheiro GHD, Fernandes MN (2002). Haematological and physiological changes induced by short-term exposure to copper in the freshwater fish, Prochilodus scrofa. Braz J Biology 62(4A):621-631.

McLeay D (1973). Effects of ACTH on the pituitary interenal axis and abundance of white blood cell types in juveniles coho salmon: Oncorhyncus kisutch. General Comp Endocrinol 21:431-440.

Mousa MA (1999). Biological and physiological studies on the effect of the gramoxon and stomp herbicides on Nile tilapia (Oreochromis niloticus). PhD. Thesis, Cairo University 220 p.

Musa S, Omoregie E (1999) Haematological changes in mudfish, Clarias gariepinus (Burchell) exposed to malachite green. J Aquatic Sci 14:32-37.

Nariagu OJ, Sprague JB (1987). Cadmium on the aquatic environment. Vol. 9A Wiley Interscience Publication $288 \mathrm{p}$.

Nussey G, Van Vuren JHJ, Du Preez HH (1995a). Effects of copper on haematology and osmoregulation of the Mozambique Tilapia, Oreochromis mossambicus (Cichlidae). Comp Biochem Physiol 111(C):369-380.

Nussey G, Van Vuren JHJ, Du Preez HH (1995b). Effects of copper on differential white blood cell counts of the Mozambique tilapia, Oreochromis mossambicus. Comp Biochem Physiol 111(C):381-388.

Omoregie E, Eseyin TG, Ofojekwu PC (1994). Chronic effects of formalin on erythrocyte counts and plasma glucose of the Nile Tilapia Oreochromis niloticus. As Fish Sci 7:1-6.

Omoregie E, Ufodike EBC, Keke RI (1990) Tissue chemistry of $O$. niloticus exposed to sublethal concentrations of Gammalin-20 and Acetellice 25EC. J Aquatic Sci 5:33-36.

Pourang N (1996). Heavy metal concentrations in surficial sediments and benthic macroinvertebrates from Anzali wetland, Iran. Hydrobiologia 331:53-61.

Reddy PM, Bashamohideen M (1989). Fenvalerate and cypermethrin induced changes in the haematological parameters of Cyprinus carpio. Acta Hydrochem Hydrobiol 17:101-107.
Shakoori AR, Iqbai MJ, Mughal AL, Ali SS (1991). Drastic biochemical changes following 48 hours of exposure of Chinese grass carp Ctenopharyngodon idella, to sublethal doses of mercuric chloride. Proc of $1^{\text {st }}$ Symp on Fish and Fisheries Pakistan 81-89 p.

Smit GL, Hatting J, Burger AP (1979). Haematological assessment of the effects of the anaesthetic MS222 in natural and neutralized form in three fresh water fish species: Interspecies differences. J Fish Biol 15:633-643.

Smith GG, Lewis WM, Kaplan HM (1952). A comparative morphologic and physiologic study of fish blood. The Progress Fish-Culturist 14:168-197.

Snieszko SF (1960). Microhaematocrit as a tool in fishery research and management. US Fish Wildlife Serv, Sci Rep 341:15.

Srivastava PN, Narain AS (1985). Catfish blood chemistry under environmental stress. Experimentia 41:855-857.

Vare L, Shimmield KB, Shimmield G (2006). Anthropogenic inputs of heavy metals to the Kongsfored area, Svalbard. Geophisical Res Abstr 8:60-79

Wedemeyer GA, Yasutake WT (1977). Clinical methods for the assessment of the effects of environmental stress on fish health. US Fish Wildlife Serv, Techn Pap 89:1-18.

Wedemeyer GA, Wood J (1974). Stress a predisposing factor in fish disease. US Fish Wildlife Serv, Fish Dis Leaflet 399 p.

Wedemeyer GA, Mcleay DJ, Goodyear CP (1984). Assessing the tolerance of fish and fish populations to environmental stress: The problems and methods of monitoring, p. 164-195. In: Cairns WV, Hodson PV, Nriagu JO (Eds.). Contaminants effects on fisheries, John Wiley and Sons, Inc., New York.

Wepener W, Van Vuren JHJ, Du Preez HH (1992). Effect of manganese and iron at neutral $\mathrm{pH}$ values on the haematology of the banded tilapia (Tilapia sparrmanii). Bull Environ Contam Toxicol 49:613-619.

World Health Organisation (WHO) (1992). Environmental health criteria 135. Cadmium. World Health Organization Geneva, 280 p. 